\title{
Švaříčková-Slabáková, R., \& Sobotková, I. (2018). Rodina a její pamět’ v nás ve světle tř́generačních vyprávění. Praha: Triton. 318 s.
}

Recenzovaná kniha vyšla v roce 2018 a věnuje se problematice rodinné paměti. Autorky navazují na předchozí publikaci Švaříčkové a kol., která je postavena na multidisciplinárním pohledu chápání rodinné paměti z pohledu čtyř vědních oborů: literatury, psychologie, historie a filozofie. Recenzovaná publikace je postavena na přístupu interdisciplinárním, a to z pohledu psychologie a historie. Pohled psychologie směřuje k chápání funkčnosti rodiny, rodinným vztahům, rodinné resilienci, pohled historie je důležitý pro pochopení společensko-historického kontextu.

V úvodu je autorkami vymezeno základní teoretické uchopení konceptu „rodinné paměti“", který chápou jako proces vyjednávání a přetváření vzpomínek tak, aby rodině dával smysl v současném světě. Kniha nás seznamuje s výsledky zajímavého výzkumného šetření, v němž byly sledovány tři pokrevně př́ibuzné generace 13 rodin, výzkumný vzorek byl vyladěn jak z hlediska nejvyššího dosaženého vzdělání, tak poměrem mužů a žen (17:22). Autorky při popisu výzkumné metody mimo jiné také poukázaly na přidanou hodnotu polostrukturovaných rozhovorů, kterou je vnímaný nový vhled do minulosti rodin. Východiskem pro strukturu rozhovorů byl dotazník Anne Muxelové. Autorkám se podařilo i při zpracování velmi soukromých témat postupovat citlivě a chránit soukromí. Při velmi rozsáhlé, systematické a obsahové analýze autorky postupovaly dvěma směry, a to po jednotlivých generacích kvůli zachycení proměn během času, a současně po jednotlivých tř́generačních rodinách, aby lépe porozuměly tomu, co je pro ně specifické, typické a neopakovatelné.

Autorky člení knihu na čtyři hlavní kapitoly, které byly sestaveny dle výsledků kvalitativní analýzy zjištěných dat. Každá kapitola má teoretické uvedení, dále následují výsledky výzkumu včetně př́mých výpovědí participantů, za nimiž nalezneme odpovědi na výzkumné otázky a možné podněty.

První kapitola „Rodinná pamět‘“ zahrnuje výpovědi rodin a jednotlivých generací o tom, jak vnímají důležitost vlastní historie, nakolik pro je ně genealogie nezbytnou součástí jejich rodinné historie, či pouhou zajímavostí nebo dokonce zbytečností. To, že historie rodu je důležitá zvláště pro nejstarší generaci, která naplňuje Eriksonovu generativitu, je očekávané, nicméně čtenáře může překvapit skutečnost, že nejmladší generace se o to zajímá mnohem více než generace střední, a ve dvou prrípadech rodinná historie zajímá dokonce pouze tu nejmladší. Pouze v jedné rodině měly o rodinnou historii zájem všechny generace. Při pročítání knihy čtenáře zaujme mnoho skutečností. Např́íklad to, že když autorky hovořily s účastníky o rodinné historii, většinou byla vztahována k současnému životu a vzpomínkám z dětství, k vyprávěním a k př́běhům, než k rodinným předkům a rodokmenům. Výzkum potvrdil zjištění jiných podobně zaměřených šetření a to, že se většinou nejedná o celistvé vyprávění, ale spíše pamět'ové fragmenty. Autorky uvádějí, že napříč všemi generacemi jsou poměrně snadno vybavovány vzpomínky na vlastní rodiče a prarodiče, částečně na praprarodiče, výjimečně na prapraprarodiče, ale neobjevují se už žádné historky a příběhy vážící se k praprapraprarodičům. Ve druhé polovině kapitoly autorky popisují, jak jednotlivé generace vzpomínají na matku, otce, babičku a dědečka. Při vyhodnocování výsledků se pozastavují nad tím, jak moc je překvapil stereotypní obrázek rodičů a prarodičů, který vypovídal napříč generacemi spíše o genderově vyhraněných rolích než osobnostních vlastnostech. 
Rodinné příběhy tedy tvoří základ rodinné paměti. Ve vyprávění nejstarších generací autorky identifikovaly v rodinné historii několik funkcí, které se vztahují jak k rodinné atmosfére, tak $\mathrm{k}$ předávaným hodnotám a tradici. Popsána byla funkce zábavná spojovaná s vytvářením dobré nálady, funkce poučení, předávání hodnot, či funkce uspokojení z kontinuity rodu. Výsledky šetření jen potvrzují, že „sdillení vzpomínek $v$ dobře fungujících rodinách je v zásadě vnímáno všemi generacemi jako důležité a stmelujicí." Autorky však velmi výstižně popisují význam vyprávění pro komunikaci v rodině a posilování rodinné resilience. Vyprávění nepř́ijemných vzpomínek může často vést k jejich narovnání, vysvětlení nepochopení a usmíření. Autorky uvádějí prŕípady čtyř rodin, které byly hodně poznamenány křivdami a bolavými zkušenostmi rodin, které na první pohled méně vzpomínaly, působí navenek tak, že raději nevzpomínají. Pokud se však mohou opřít o vnitřní sílu rodiny a zraňující vzpomínky nezevšeobecňují, hledají to pozitivní z nich, využívají tedy selektivitu vzpomínek jako nezbytnou vlastnost pro zpracování a zapracování, čímž je současně posilována rodinná resilience. Nicméně jak samy autorky na závěr konstatují, „umění je rozlišit, co je podstatné a má být vyjasněné, a co je možné nechat být."

Druhá kapitola „Vzpomínky a dětstvi““ souvisela s cílem popsat vzpomínky na dětství ve vícegeneračním kontextu, protože pozornost tomuto směru výzkumu nebyla dosud v odborné literatuře věnována.

Autorky se snažily zkoumat psychologickou, emocionální, vztahovou a hodnotovou stránku vzpomínek v multigeneračním kontextu. Popis toho, jak vzpomínají participanti na dětství a co by přáli dalším generacím, autorky představily už ve své předchozí knize „I rodina má svou pamět"“ (2018). Nyní se rozhodly zkoumat to, co by účastníci výzkumu ze svého dětství dalším generacím nepřáli zažít. V rámci analýzy zjištěného byly analyzovány dvě hlavní kategorie. Do první z nich patři osobní a rodinné okolnosti, nejčastěji zmiňované špatné vztahy, rozchody, smrt a zdravotní problémy. Druhou tvoří nepříznivé vzpomínky vážící se ke společensko-historickým souvislostem. Bylo potvrzeno výpověd’mi nejmladší generace, která neuměla vyjmenovat společenské dopady, jež by svým dětem v budoucnu nepřála, že nelze vnější okolnosti a jejich vliv na rodinnou historii vynechat, ale současně můžeme žít v době, kdy vliv těchto okolností není nijak významný. Tento trend autorky velmi pozitivně hodnotí, pokud se budeme tedy více snažit o dobré vztahy v rodinách, rodiny budou funkční, budou i podmínky pro vývoj dětí optimální. Nicméně faktem zůstává, že větší váhu má atmosféra v rodině než vnější vlivy.

Zajímavou částí vyhodnocovaných polostrukturovaných rozhovorů byly také otázky týkající se vzpomínek a smyslů. Nejčastěji se objevovala vzpomínka ve vztahu k chutím a vůním, a to jak v pozitivním, tak v negativním smyslu (asi mnoho z nás si vybaví vůně některých jídel ze školní jídelny, které nás obrátily dříve, než jsme došli k výdejnímu okénku). Druhým, nejčastěji popisovaným smyslem, byl sluch, který se na rozdíl od chutí a vůní vázal spíše na veřejné prostranství. Nicméně tyto vzpomínky patřily spíše střední a nejstarší generaci, často se vázaly na zvuky z války nebo jiných společensko-historických událostí. Smyslové vzpomínky se dle autorek váží velmi často na emoční stav člověka.

Pozornost je věnována také vazbě k místu vzpomínky, i v tomto šetření se potvrdilo, že čas je pro vzpomínky nespolehlivá proměnná. Dále byl např́klad zkoumán vztah k rodinám otců a rodinám matek, který se z největší pravděpodobnosti vytváří podle subjektivně vnímané citové blízkosti. V knize jsou velmi výstižně vybrány citace participantů vysvětlující jejich rodinné chování, autorky hledaly podobné vzorce chování. 
Třetí kapitola je věnována mezigeneračnímu přenosu. Autorky výzkumu zajímalo, zda se rodiny i v dalších generacích schází, zda se v rodinách předávají nějaké zvyky a tradice, uchovávají fotografie či památeční předměty. A souvislost byla prokázána. Zajímavé zjištění bylo např́klad to, že způsob mezigeneračního učení se během času proměňuje. Současné generaci nevyhovuje dříve zvyklý model „ted' se dívej a naučíš se to“, ale upřednostňuje nenásilné učení, vzájemnou komunikaci, sdílení a pocit dobrovolnosti. Proto autorky doporučují mladou generaci učit tím, že starší předávající generace musí využívat společných momentů a situací, v nichž nenátlakově zkušenosti předá. Výhodou současné doby je posilování role prarodičů, kteří se dožívají vyššího věku, než tomu bylo dříve a mají mnohem více příležitostí předávat nejmladší generaci. Pochopitelně je tento přenos oboustranný, děti mohou pomáhat prarodičům zorientovat se v současné rychlé době plné technických novinek.

Čtvrtá kapitola je vztahována k poselství rodiny. Autorky se zaměřily u svých participantů na to, co považují ve své životní historii za nejdůležitější a co by rádi předali dalším generacím svých rodin. Jednoznačně se potvrdilo, že odkaz se týká zvláště důrazu kladeného na funkčnost rodiny, která musí svým členům vytvářet bezpečné prostředí.

Rodinná historie propojuje jednotlivé generace, zajišt'uje rodinnou kontinuitu a integritu rodiny. Rozhodně recenzovaná kniha přinesla mnoho podnětů jak pro další psychologické zkoumání, tak mnoho otázek ryze lidských a osobních. Přiměje čtenáře ke spoustě poznámek a podnítí v něm touhu orientovat se, zaznamenávat, vyhledávat, zpracovávat a uchovávat co nejvíce informací o vlastní rodině dříve, než se ztratí. Už dlouho jsem nečetla tak podnětnou knihu, jakou byla právě tato.

Marta Kolaříková 